\title{
PROPERTY RIGHTS IN KAIAPOI
}

\author{
Te Maire Tau*
}

\begin{abstract}
Māori property rights have been a much discussed topic over the years, but often under false assumptions and pretences. Traditionally accepted views highlight the communal nature of Māori property rights prior to European contact. It is now assumed that individual rights or property rights were a Western construct imposed on Māori, who it is believed held land in common. This article argues that there was no contradiction in the idea of a tribe holding its territory as a collective while also having individual ownership of land and resources. At the same time we need to be careful of over-extending western notions of property to Māori or any other non-western peoples, an outcome of the colonial narrative. This article attempts to remove the idea that property rights among Māori were communal and that individual title rights did not exist. It will do this by looking at the "Kaiapoi Experiment" of 1859.
\end{abstract}

The object of the Native Lands Act [1865] was ... the detribalization of the natives - to destroy if it were possible, the principle of communism which ran through the whole of their institutions ... It was hoped that by the individualization of titles to land, giving them the same individual ownership that we ourselves possessed ... their social status would become assimilated to our own. ${ }^{1}$

\section{INTRODUCTION}

If there was ever an overcooked sentence when dealing with Māori land law, it must be Henry Sewell's explanation to the Native Land Act 1865 and his declaration that its purpose was to end tribalism and stamp out the communism of the Māori. MPK Sorrenson brought Sewell's declaration to our attention in his still superb article "Land Purchase Methods and their Effect on the Maori Population, 1865-1901". Here, Sorrenson explained how the Native Land Court's implementation of individual title was used to undermine the collective authority Māori had over land and once the chink was identified through individual title, there was little the community could do: ${ }^{2}$

* Associate Professor and Director of the Ngāi Tahu Research Centre, University of Canterbury.

1 Henry Sewell (29 August 1870) 9 NZPD 361 cited in MPK Sorrenson "Land Purchase Methods and their Effect on Maori Population, 1865-1901" (1956) 65 Journal of the Polynesian Society 183 at 185.

2 MPK Sorrenson, above n 1, at 186 (citations omitted). 
The beginning of the process was simple. European purchasers could nearly always find one or two individuals of the tribe who were willing to sell land. If they did not make a cash advance they called on the assistance of the local storekeeper or publican, who often acted as "Native land agents" and who offered the Maoris liberal supplies of goods and liquor on credit. Through debts a hold was obtained on the Maori and his land and the next stage was to bring the law to bear on transactions. If Maori debtors were recalcitrant Europeans could always threaten civil law suits and imprisonment for non-payment of debts.

Any historian who has worked the land court records will understand this story. It is one repeated throughout the length of New Zealand and is really a statement of shame for New Zealand's judicial system and the immoral nature of speculation on Māori land that continues today.

Since Sorrenson's article, Sewell's quotation has been used often enough and herein lies the problem that this article shall tackle. Our understanding of "take whenua" - Māori land tenure - has become distorted and we should not be surprised that elements of the colonisers' ideas have been assimilated into what we now believe to be our traditional customs to our land. ${ }^{3}$ It is now assumed that individual rights or property rights were a Western construct imposed on Māori, who it is believed held land in common. Yet, despite the fact that Sewell had no real understanding of takewhenua - rights to land, food gathering places and fishing sites - Māori continue to use it as a reference to equate customary land tenure with communal tenure. It is easy enough to see why Māori react to Sewell's statement. The insidious colonial narrative that cast property rights in this manner has been accepted by many Māori and the wars that ripped the North Island apart only served to reinforce the sanctity of communal tenure, as the conflagration is seen as having spiralled towards disaster because of the Crown's underhanded move to purchase land individually. Nonetheless, for Māori, Sewell's views should be irrelevant when Māori deal with take whenua. Unfortunately, this is not the case. The Waitangi Tribunal continues to adhere to the belief that land was communally held and individual property was not customary. ${ }^{4}$ Similar statements are found throughout contemporary assessments of customary land tenure and the simple fact is that they are incorrect.

This article argues that there was no contradiction in the idea of a tribe holding its territory as a collective while also having individual ownership of land and resources. Both concepts were entirely compatible. For land to be owned on both a communal and individual basis, a community had to exist - whether a tribe, a feudal state or a nation state. At the same time we need to be careful of over-extending Western notions of property to Māori or any other non-Western peoples, an outcome of the colonial narrative. There are as many varieties of property as there are of capitalism,

3 See an alternative view in Lyndsay Head "Land, authority and the forgetting of being in early colonial Maori history" (PhD Thesis, University of Canterbury, 2006).

4 See for example Waitangi Tribunal The Ngati Awa Raupatu Report (Wai 46, 1999) at 78; and Waitangi Tribunal The Report of the Waitangi Tribunal on the Orakei Claim (Wai 9, 1987) at 20. 
community institutions, nation states and banking systems. In fact, it is also important to understand that while Western property rights have become a streamlined and almost universal system, this is only a relatively recent development and historically they too showed a variation and intricacy similar to Māori tenure. This article endeavours to remove the idea that property rights among Māori were solely communal and that individual title rights did not exist. It will do this by looking at the Kaiapoi Experiment of 1859.

Kaiapoi is the traditional name of the largest Ngāi Tahu fortress in the Canterbury region of the South Island. Until its destruction in the summer of 1831 by an enemy tribe, it was the principal stronghold of the tribe who controlled most of the South Island of New Zealand. Shortly after the peace settlements and the end of warfare, Ngāi Tahu were forced to negotiate with the British Empire, which wished to purchase 20,000,000 acres of land in the South Island for $£ 2,000 .{ }^{5}$ This acquisition was known as the 1848 Canterbury Purchase and constituted roughly two thirds of the South Island. The Canterbury Purchase followed the Treaty of Waitangi and although we tend to see the Treaty of Waitangi as the nation's founding document, it is also helpful to see the Treaty of Waitangi as the first among many. In simple terms, the Treaty of Waitangi allowed the Crown the right to purchase land from tribes. Those purchase deeds were more than formal land transactions because the deeds also contained promises, assurances and specific provisions for iwi members that did not appear in a normal land transaction. For this reason, the purchase deeds are best seen as separate tribal "treaties" as opposed to the national Treaty first signed at Waitangi in 1840.

From a Crown perspective, the Canterbury Purchase meant that the bulk of the land was now Crown property which could be granted to the settlers by way of the Crown Grants Act (No 1) 1862. For Ngāi Tahu, there were two issues before the land could be "granted" to them as tribal members. First, the land that had been reserved for tribal members was simply placed aside. That is, the land was still customary land and was outside Crown title. Secondly, for it to be granted to tribal members, it had to first pass through the Crown's land office wherein the Crown could then grant it to tribal members with a certificate of title.

However, it is the gap between the actual granting of the land by way of a special Act known as the Crown Grants Act (No 2) 1862 and the formation of the community into a rūnanga (council) in 1859 that provides some fascinating insight into how Māori attempted to articulate and retain their traditional tenure. The reason this experiment deserves attention is that the land was granted outside of the Native Land Act 1865 and was meant to have been regulated by the community in rūnanga (in council). Part of the regulations provided for the right of individual title and communal

5 Harry C Evison Ngai Tahu Land Rights and the Crown Pastoral Lease Lands in the South Island (Ngāi Tahu Māori Trust Board, Christchurch, 1986). 
properties, on the condition that the land could only be alienable among members of the tribe. ${ }^{6}$ In other words, the land was tribal land that acknowledged individual property.

In 1862, while the first Native Land Act was still a Bill before the House of Representatives, James Fitzgerald, the Canterbury member for Ellesmere, made an interesting observation on whether the Native Land Court was really needed: ${ }^{7}$

... the Government [should] have extended their runanga system and made it a provincial system. The Native Lands might then bear the same relation to the runangas as the waste lands of the Crown did to the Provincial Government - that was, if they wanted to sell or lease the land it would be for the runanga of the district to make regulations for it. The district runanga had been told that it should have the disposal of the lands; what, then, was the use of bringing down a Bill saying that this Court should have the power?

For Māori, this is a fascinating statement of what could have been - their village councils or rūnanga would have had the same function on their lands as the Provincial Council would have had on the Crown lands within its region. In this scenario, the issue of individual title is really a secondary matter to what Māori would see as a statement of mana-motuhake or self-governance. Despite Fitzgerald's entirely reasonable position, the Bill was passed. The Native Land Court became a fact. One of the driving reasons behind the passing of the Bill was the constant belief that Māori land was "communal" and that their "beastly communism" needed to be eradicated. ${ }^{8}$ Nonetheless, even a cursory glance at the primary evidence of Māori land tenure and in fact the world in which they lived showed how their land tenure was anything but rooted in communism. Yet the idea persists to this day, leading to the most obvious question, how did the notion of communism and Māori land tenure become synonymous?

As early as 1929 the anthropologist Raymond Firth expressed concern at the way in which communal title was used to describe Māori land when he wrote his canon, Primitive Economics of the New Zealand Maori. ${ }^{9}$ Amongst his many insights, Firth argued that Western scholars had always had a tendency to impose their own ideals (and fears) upon non-Western people and how "in recent years" the idea of "primitive communism" had gained currency, noting that Māori were being labelled as "communist". ${ }^{10}$ Firth was before his time. In the decades after his seminal work, the

6 Walter L Buller "Final Report on the Partition and Individualization of the Kaiapoi Reserve" [1862] I AJHR E5 at 3.

7 (26 August 1862) NZPD 628

8 (3 August 1860) NZPD 186.

9 Raymond Firth Primitive Economics of the New Zealand Maori (rev ed, Routledge, London, 2011).

10 At $358-359$. 
fields of post-colonial studies and psychology would begin to explore this very phenomenon, of projecting Western values, beliefs and assumptions onto non-Western people to justify colonisation.

Firth, whose book title itself reveals the influence of the narrative, sought to map out the influence of what is now known as the colonial narrative. He examined the writings of Elsdon Best, who spoke of Māori as an "interesting communistic and Neolithic people". ${ }^{11}$ Firth also discussed the Native Land Court Judge JA Wilson, who stated "the Maori was a thorough communist". ${ }^{12}$ The review that Firth undertook was impressive, tracing how influential scholars, New Zealand politicians and Native Land Court judges had created the idea of Māori society as an early form of a communist society. Firth managed to dismiss the idea of Māori as a communist peoples saying that "the idea of an absolute community of goods is not endorsed even by the most casual study of such facts". ${ }^{13}$ Interestingly, he then added that most scholars understood that private ownership existed but have kept the term communism to describe the general system of "property holdings". ${ }^{14}$ Firth finally concluded that: ${ }^{15}$

To apply the term to any vague form of group activity or group control is only to introduce needless

confusion ... Such has actually occurred with regard to the Maori scheme of ownership.

Elsewhere he said with some annoyance that "at times it appears to be used as a kind of catch word, with no relevance at all". ${ }^{16}$

\section{TAKE WHENUA - THE NATURE OF NGĀI TAHU PROPERTY}

As will be shown, there was nothing remotely communist about Ngāi Tahu property rights. Whenever Ngāi Tahu members moved upon the island, they did so along largely defined family pathways and territories. They did not roam on a random basis upon lands and sites that did not belong to them. Ngāi Tahu had a term for this type of person: "he kāka kai-āmio" - parrots who eat here and there, roaming with no territory of their own. The idea of moving from one spot to another where they had no ancestral connections was something to look down upon. The term used to describe a people with no rights was "poke-tara" - a mushroom that suddenly appeared in the morning, without roots, disappearing by mid-morning. ${ }^{17}$ Having take whenua encompassed an
11 At 359 .
12 At 360 .
13 At 360
14 At 362 .
15 At 363
16 At 364
17 Herries Beattie "Our Southermost Maori" Otago Daily Times (Dunedin, 1954) at 54-55. 
enormous amount of the tribe's oral traditions. Families made sure that their descendants knew the rights they had to the lands they hunted so that their "take" - their claims or rights - could be argued and secured before the tribe.

Edward Shortland, who held the Office of Protector of Aborigines, gave one of the better explanations of what customary Māori title meant in practice during his investigation of the South Island land claims in 1843. Although the passage is lengthy, it is worth quoting: ${ }^{18}$

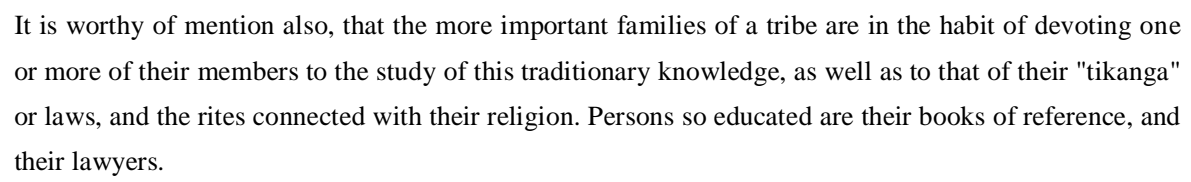

When the right to a piece of land, or its boundaries, is disputed, these native lawyers are appealed to, and the case is investigated before all interested, generally near the spot in dispute. The counsel for the plaintiff opens his case by naming in a loud voice some ancestor, A, of his party, whom he calls the root of the land. "Ko Mea te taki o te kaigna._ Na ___ "So-and-so is the root of the estate. Now then ___" is the form of words in which they invariably commence. He then endeavors to prove that this root exercised some right of ownership undisputed by any one, and deduces, step by step, the descent of his clients from this ancestor or root.

The families that Shortland spoke of were relatively small. Atholl Anderson, suggests the hapu units averaged between 10-30 members, which we would call whānau - or extended family units today. If we average the family grouping to 15 members, it is easy enough to see that the whānau would have consisted of the family elders, children, spouses' sons, daughters and grandchildren. As we shall see later in the article, we know that one of the elders, the grandfather or grandmother would have held been acknowledged as the pu-take - the owner, or the source - of rights. The specific phrasing was that the elder had a take - a right - to land. How this right was fashioned and formulated within the community, among individuals can only be understood by going to what the elders actually tell us.

One of the earliest statements of take whenua claim made in the South Island was by Teoti Metehau, an elder of the Kaiapoi village. Metehau made his mark in 1848 after the tribe had gathered at Akaroa on the South Island of New Zealand to sign the Canterbury Deed of Purchase. Shortly after Kemp had completed the negotiations and had returned to Wellington, Walter Mantell was sent to Canterbury to visit the tribe and to survey the lands, wherein the tribe would be located onto lands reserved. ${ }^{19}$ This is where the gap between assurances made by the Crown and

18 Letter from Edward Shortland to G Clarke regarding the nature of Māori land tenure (15 August 1843) Edward Shortland Papers MS 86A (University of Auckland).

19 Evison, above n 5, at 22-24. 
expectations from the chiefs fell short. The Deed made specific reference to the Crown setting aside areas of residences - "kāinga nohoanga" - and food gathering sites - "mahinga kai" - for the tribe. ${ }^{20}$ For tribal members this could only mean that their tribal rights and tribal title would be recognised.

Metehau, who had not signed the Deed of Purchase, immediately made his claims known to Mantell and he soon moved towards recording all his interests in writing for his descendants so that they would know their claims to their land. It is a fascinating manuscript because he outlines the areas that his ancestors traded valued family weapons, canoes and cloaks for fishing grounds, valleys and gardens. On 22 February 1849, Metehau sent a letter to Queen Victoria outlining the lands he owned. Rather than outline the whole letter, I shall refer to two particular claims he made to two mountains within what is now known as the Torlesse Range. Metehau told the Queen: ${ }^{21}$

\footnotetext{
Ehara i te wenua nunui enei pihi e tuhia atu nei e au ki a koe, he wahi ririki nei ... he kainga no matou tupuna tuku iho ki a matou matua a taea noatia mo matou nei, ko ka wahi ano i taku matua, koia ano hoki ahau I tuhi atu nei ki a koe - Ko te pihi tenei I au o te Kuratawhiti, Ko to Tawera. ${ }^{22}$

These pieces of land that I write to you about are not large, they are small ... left to us by our fathers right through to the present. These are places from our forefathers that I write to you about - they are pieces on the mountains, Kura-tawhiti and Tawera.
}

Kura-tawhiti and Tawera are two mountains that are part of the Torlesse Range. His claim is not to the mountain itself, but to specific small pieces on that mountain. Earlier in 1848, Metehau had sent a letter to Mantell saying: ${ }^{23}$

Kia roko mai koe, ko ka wahi ano i au o Tuahiwi, kei au ano ko ka wahi ano i au o Kaiapoi, kei au ano

Ko Tawhera, ko te wahi ano i au, kei au ano ko te wahi o Te Kuratawhiti kei au ano

May you heed my requests. My lands in Tuahiwi lay with me as do my lands at Kaiapoi. Again, my lands at Tawera are mine as well as the land of Kura-tawhiti.

20 At 21 .

21 Letter from Teoti Wiremu Metehau to Queen Victoria (22 February 1849) in "Letters and Memoranda etc" (Ms 1530, 1845-49, 56, Series 2/1 Walter Mantell: Official correspondence and notes, Alexander Turnbull Library) 56-66 (author's translation).

22 Head is critical of the term "pihi" which meant a "piece" of land rather than the more traditional "wāhi" which means an "area" of land; see Lyndsay Head, above n 3 at 178-181. However, Metahau is always clear on the ancestral roots of his lands and he is also clear that his lands were ancestral and not to be sold. It is more likely that when Metehau uses "pihi" he is using this term rather than the older word, "wakawaka". What is interesting to the Metehau letters is that he does not refer to his take to the lands. Instead Metehau gives the kōrero or his stories to the lands, which implies a sense of past and ancestral connections that Head refers to

23 Letter from Teoti Wiremu Metehau to Walter Mantell (circa 18 October 1848) in "Letters and Memoranda", above $\mathrm{n} 21$ 
Metehau's assertion was not unique. His example has been used because he took pains to record his ancestral lands. What is important is that this situation appears to have been the norm.

The idea of specific property rights within this tribe is exemplified by the Tìtî Islands of Rakiura (Stewart Island) where tîtī (sooty shearwater) nest. During the autumn months, tribal members with take as far north as Kaiapoi would make their way to these islands to gather the tîtī. The islands were divided into different areas (manu) for each family to work. From the position of the family, these manu belonged to the family elder with rights and they would have challenged any idea of a collective tribal title. During the hearings of the Native Land Court for the island of Papatea, one elder explained the property rights as follows: ${ }^{24}$

My knowledge of the claim is that a canoe was made near Molyneux by two natives named Wera \&

Tahu ... Wera and Tahu bought the island Papeta from the owners by the gift of the canoe alluded and

some "bullets". ${ }^{25}$... The island was divided into sections and named after certain ancestors ... the

partition called Te Rangitamau belonged to Pae and has been held by his descendants to the present

time. Another portion was called Wakataupuka, another Wareko, this part belongs to Kihau's family

The purchase or trade of land was common among Ngāi Tahu and examples can be found throughout the island. The word used throughout the transactions is "utu" and we should not drag ourselves down in debating the anthological differences over the words "trade", "payment" or "exchange". What they did is important. Metehau gives an example of utu in his ōhākī of how his family had rights to a place called Omihi: ${ }^{26}$

Ko Mihi kaika e whenua utu tera kaika i utua kia Tuhoro ma te utu he waka nui tona ikoa Ko Toroa he utu mo Paritu puta noa ki uta puta noa ki tatahi ki Te tauraka ki Kawaroa Ko ka wenua tenei i utua ai e oku Poua e okua matua.

There is Mihi. This place ... was paid for to Tuhoro and his folk; the price was a large canoe. Its name was Albatross. This was payment for Paritu, thence proceeding inland and by the coast to Tawaka and to Kawaroa. These are lands paid for by my forefathers.

All through the South Island, the land was divided into family areas of mahinga kai. These sites were specific and from the perspective of the whannau, held by the family elders. If the 1846 document is read with his letter to Queen Victoria in 1849, Metehau is claiming eight pieces of land on Tawera. His claims are specific to himself, his brother and sister and in that sense they are individual in their nature. These "pihi" are really a transliteration of "pieces". The word used by

24 (1887) 5 South Island MB at 32.

25 The original text had "mata" which I have replaced with "bullets".

26 "Ohaki of Teoti Wimemu Metehau" (circa 22 November 1846, Private Collection, RTM Tau Archives, Tuahiwi). 
Ngāi Tahu is "wakawaka". ${ }^{27}$ Wakawaka barely appears in the North Island and is heard less often today. But in the 19th century the word was known among the tribal members and used the term when describing sections and divisions of land set aside for whānau and hapū. In fact when the Otago Purchase occurred in 1844, one of the agreements that the Crown made with Ngāi Tahu was that a tenth of the land would be set aside as reserves. These tenths were called "wakawaka" by Ngāi Tahu leaders present at the purchase. ${ }^{28}$

\section{WAKAWAKA: THE BOUNDARIES}

The Royal Commission of 1879 (the Smith Nairn Commission) called the southern member for Parliament, HK Taiaroa, to explain wakawaka. Taiaroa provided the following explanation: ${ }^{29}$

\footnotetext{
He wakawaka ano te ingoa. No kona ki the ki au atu ahau ki tetahi tangata o Ngai Tahu ki the kupu wakawaka, mohio tonu mai the tangata ki taua ingoa ki the wakawaka, ko taua whenua ka wakawakatia ara tona tikanga tona tikanga e mau nei
}

The word for those divisions is wakawaka. From that basis, whenever I speak to someone of Ngai Tahu about the word wakawaka, that person will know that word wakawaka and that that land has been sectioned off and each has its own traditions and customs.

In his evidence, Taiaroa drew a series of lines running across a page to explain the divisions of land. The elder, Taare Tikao explained wakawaka as follows: "Bird preserves were kept in families and trespassing was a grievous offence. Boundaries were called wakawaka and preserves [reserves] rauiri, as were also eel reserves in the river." 30

Earlier in his narrative Tikao goes on to explain his connection to the Torlesse Range where he claims the mountain, Whata-a-rama, which stood alongside Tawera and Kura-tawhiti: "I am descended from that family and my ancestors used to go to Te Whata-a-rama ... to hunt pigeons, kaka and weka". ${ }^{31}$

The Torlesse Range was primarily an area where forest fowl, such as the kākāpo mountain parrot were taken along with the kiore (a native rat) that occupied the forests because they ate the

27 Williams simply refers to wakawaka as "Ridge and furrow, row, bed in a plantation" or as a "Share, division": see William Williams A Dictionary of the New Zealand Language (Church Mission Press, Paihia, 1844)

28 Waitangi Tribunal The Ngai Tahu Land Report (Wai 27, 1991) at [6.6.8]-[6.9].

29 See Sarah M Williams "Maori Language Papers Selected from the Taiaroa Papers and Translations" (Wai $27, \mathrm{~S} 12,1991)$ at $23-24$, inquiry document for Wai 27 , above $\mathrm{n} 28$.

30 Teone Taare Tikao and Herries Beattie Tikao Talks: traditions and tales told by Teone Taare Tikao to Herries Beattie (Reed, Dunedin, 1939) at 136 (emphasis in original).

31 At 89 (emphasis in original). 
seeds from the beech trees. It is safe to assume that when Metehau writes of his eight pieces of land on Tawera, he was referring to his wakawaka.

For all intents and purposes, the land and the sites mentioned were the property of Metehau. In this sense, the property right could be couched in terms of it being a property right of the whannau rather than the individual, but this is a matter of splitting hairs. In Māori custom, Metehau had inherited the right from his ancestors. The children did not have a right because their parents still held those descent lines. Metehau could have equally traded these lands with his relations to the exclusion of his children. Neither was the right to inherit absolute or one that could be assumed as natural. ${ }^{32}$ Ironically, the situation is somewhat analogous to Western property rights, where there is an expectation that direct family will inherit property but until the owner dies they have no right to the property and the owner usually is specific as to which family member inherits, if at all.

The extent to which Ngāi Tahu records deal with wakawaka is fascinating as their boundaries extend through to the kiore trails that dominated the Torlesse region and Canterbury. Many boundary divisions and hapū areas were compiled by HK Taiaroa, who became the Member of Parliament for Southern Māori in 1871. By 1880, the tribe had gathered to help him record all the mahinga kai traditional sites within the Canterbury region south to Ōtākou. At Kaiapoi, seven elders as well as 30 others attended the meeting where they proceeded to outline 219 customary sites within the Kaiapoi boundaries, which generally stretched from the Hakatere River northwards to Kaiapoi following the inland range. ${ }^{33}$ We can see from the sites, when placed against other tribal records that they tend to fall within a series of smaller hapū wakawaka that follow natural boundaries. It is also apparent that the elders are also recalling their own specific sites within the overall matrix of the 219 names given. The picture that emerges from the data is that when these elders were speaking of hapū they were really speaking of small whānau units, which aligns with Anderson's view that the hapu averaged 10-30 members. The population at Kaiapoi during that time would have amounted to 300 at most and we can see that at the actual meeting there were seven elders and 30 others in attendance. The elders were recalling each site that was specific to them as individuals. ${ }^{34}$ The Ngāi Tahu reference to hapū, is a reference to whānau. Furthermore, those

32 This is still the custom practiced on the Tìtī Islands further south near Stewart Island. The Tītī Islands are a series of islands that surround Stewart Island of New Zealand. Tribal members have regularly travelled to these islands to harvest the sooty shearwater during the autumn months (March-May). While the location is different, the practice is still one of harvesting forest fowl and the division of whānau boundaries and property rights remain the same. Also, the rights belong to the family heads, not the family as a collective unit.

33 Supporting Evidence of Rob Cooper "Mahinga Kai Sites 1880" (Wai 27, R30, 1991) inquiry document for Wai 27, above n 28 (confidential).

34300 is a rough estimation of the Kaiapoi population. Walter Buller allocated the land to 122 adults, mostly male. However a good many of these adults also came from Bank's Peninsula villages to be included in the allocations. The population could have exceeded 350, although I simply have my doubts. See Buller, above n 6, at 6-8 
whānau worked their areas independently. In the following account, one elder explains how different hapū operated when working their different plantations of the Tī (Cordyline australis), to produce a sugary fibre known as kāuru: ${ }^{35}$

As the fifth month (September) drew to an end, each hapū starts to leave the larger Pah for the open land, the foothills or the valleys to work the cabbage tree or kāuru. Hapu go directly to their own area of mahinga kai as they have their own plantation. Hapū do not go another hapū area and to work without consent. This is an important custom to our people, to never trespass onto and work another hapū's area.

The same elder makes the same observation when different hapū went to Te Waihora: ${ }^{36}$

A man from one hapū would never go to another hapū to take eel. This offence would never happen ... .

These behaviours are from our ancestors from along ago, handed down from one ancestor to the subsequent.

It is apparent from the historical record that Ngāi Tahu property rights were structured and while they were communally validated, they were individually held. Indeed, it may be more accurate to say that the territory was defended as a community. The minute degree to which Kaiapoi was divided was a pattern that ran throughout the island. The Canterbury region itself was divided into eight regions or wahaka which were in turn further sub-divided into hapū territories. ${ }^{37}$ The question, then, is how was this idea translated into contemporary requirements once the land purchases required the kind to be granted back to tribal members in Crown title and how did these traditional stories influence these conceptual translations? There have been two occasions in the tribe's history when it has attempted to articulate its customary practices as modern property rights. The first was at Kaiapoi when the people established what could have been the first rūnanga to have been in operation as a working model before Grey had initiated his "new institutions". ${ }^{38}$ The second was the 1925 Ngāi Tahu hui, again at Tuahiwi, when tribal elders allocated individuals their "shares" to the $£ 350,000$ recommended from the 1920 Royal Commission.

\section{THE KAIAPOI EXPERIMENT}

The assumption had always been that once the Crown purchased land from Māori, the land would automatically pass into Crown title, which allowed the Crown to do with it as it wanted

35 Elsdon Best Forest Lore of the Maori (EC Keating Government Printer, Wellington, 1977) at 390-392 (translated from the Māori text by the author).

36 Elsdon Best Fishing Methods and Devices of the Maori, (EC Keating Government Printer, Wellington, 1977) at 241 (translated from the Māori text by the author).

37 Matiaha Tira Morehu refers to eight regions that were divided by the rivers. Those districts were Purehurehu, Waipatu, Waihemo, Waitaki, Mahikihiki, Hakatere, Waikirikiri, Kaiapoi. (Rawiri Mamaru MS, Author's Personal Collection).

38 The Kaiapoi Runanga was the first "experiment" in the new institutions idea: see Buller, above n 6, at 3. 
according to the laws of the land of the United Kingdom in this instance. This meant that the Crown could then grant land to the settlers through sale or auction. For Māori the situation was less certain. The deed of purchase for Canterbury stated that land would be set aside for Māori as reserves. ${ }^{39}$ However, from 1848 through to the actual granting of the land to Māori in 1865, the land remained, for want of a better term, extra-legal. That is the land was outside the law. It could be argued that the land still remained in customary title and this would be partially true inasmuch as it was not Crown land. However, while the Crown would have seen the land as customary, this may not have been the case for Māori.

Between 1848 through to the early 1850s, Ngāi Tahu were still occupying land in North Canterbury along customary lines and had not relocated to the Kaiapoi Reserve. ${ }^{40}$ The reasons for this are unknown, although it is probable that the lands reserved at Kaiapoi belonged to a particular hapū. As seen in the earlier accounts, the whole Kaiapoi region was sub-divided into wakawaka. Eventually, the tribes were relocated onto the Kaiapoi Reserve and this is where trouble arose because the customary owners in this area now had other hapū contending for rights. In this sense, the land may no longer have been "customary" in their eyes, although neither was it a Crown grant in a legal sense. This is why the best term may be "extra-legal", in that the land sat outside the law and customs of Māori and the Crown. The problem needed to be resolved.

Upon his return to New Zealand, Metehau demanded to know how it was that the other Kaiapoi leaders had a right to land in his area. In his view, the chiefs had signed the deed of purchase and therefore ceded their rights to the land. ${ }^{41}$ Metehau was not alone. Some of the senior chiefs automatically claimed their traditional fishing spots, gardens and burial grounds along the Whakahume River - which bounded the reserve. ${ }^{42}$ Despite the fact that other hapū were relocating to Kaiapoi, the available evidence shows that the chiefs were allocating members plots for their houses, deciding where the burial sites would be and where families could garden and fish. ${ }^{43}$ However, this does not mean tension did not exist. Arguments continued for the next decade and were finally resolved when the people met in-rūnanga in 1859 when Walter Buller arrived to report on their condition. ${ }^{44}$

Walter Buller was appointed Native Commissioner for the Southern Provinces in 1854 and in 1859 he was asked to visit Kaiapoi and to report on the well-being of the people there. Buller soon

39 The Ngai Tahu Land Report, above n 28, at 413-414.

40 At 671-672.

41 Letter from Teoti Wiremu Metehau to Queen Victoria, above n 21.

42 (1886) IC South Island MB at 170-291.

43 At $170-177$.

44 Buller, above $\mathrm{n} 6$ 
learnt of the tensions that were mounting and quickly moved to mediate the problem by encouraging the people to establish a rūnanga so as to decide on what to do with the land. In his introduction Buller stated that he "urged the partition and individualisation of the land and the issue of Crown Grants to the Natives, in severalty, as the only effectual remedy for the evils complained of". ${ }^{45}$ While Buller overstated his position, he was the agent that led to a fundamental change in how the land was to be managed. Buller stated: ${ }^{46}$

At a public meeting of the Kaiapoi Natives, when this subject was under discussion, I elicited their sentiments by putting forward the following suggestions; all of which met their approval.

1. That the primary subdivision and apportionment of the land should be arranged by them in Runanga.

2. That as a fundamental condition of the proposed grants, the estate and interests created thereby should be entailed, so as to make them inalienable to persons of other than the Maori race.

3. That the power of leasing, if allowed, should be modified by certain conditions or limitations.

4. That the whole of the attendant expenses should be borne by the Natives themselves, - a sufficient portion of the land being set apart for that purpose.

5. That suitable endowments should be made for the several objects of Churches, Schools, and Hospitals.

6. That the arrangements contemplated in the two foregoing clauses should be carried out prior to the apportionment of the land (i.e. whilst it is common property).

It has been suggested that Buller exceeded his authority and thereby imposed his views of individual title upon the community. ${ }^{47}$ This view obscures the fact that individual property rights were the norm and that the Kaiapoi people asked for their lands to be individualised through subdivision. Interestingly, Mantell said that in Kaiapoi the "proprietorship is more minutely divided than in any other place which came within the sphere of my operations". ${ }^{48}$ Soon after Buller's

45 At 3 .

46 At 3 .

47 WE Rawson "Report and Evidence of the Royal Commission on the Kaiapoi Reserve" [1911] I AJHR G5 at 7 and 41

48 Letter from Walter Mantell (Commissioner for Extinguishing Native Claims) to the Colonial Secretary (30 January 1849) as reproduced in CW Richmond "Report Relative to the Land Purchases and the Condition of the Natives in the Middle Island" [1858] I AJHR C3 at 4. 
proposal had been made in December 1859, the Canterbury Ngāi Tahu gathered at Lyttelton to meet the Governor to ask that he approve their idea of individual title. Their petition read: ${ }^{49}$

The voice of all the people is that our land Reserves be subdivided, so that each may have his own portion. We ask you to give to each man a title in writing to his own allotment. But we leave the matter in your hands $\mathrm{O}$ Governor. Our reason for urging the subdivision of our land is that our difficulties may cease, that we may live peaceably

Governor Gore-Browne gave his personal assurance in this matter, when meeting with the assembled Kaiapoi Natives at Lyttleton: "I shall then recommend to the Queen that titles similar to those of Europeans should be issued to such individuals". ${ }^{50}$ This is likely to be the origin for a unique Act, called The Crown Grants Act (No 2) 1862.

For the Crown, the problem was not that Māori property rights were communist but rather the system of rights was simply too complex to master, leaving them to use the blunt ideology of communal title. A sharper mind was required to frame their system. The Crown Grants Act (No 2) 1862 was the Crown's attempt to resolve the extra-legal situation that the Kaiapoi people had found themselves to be in by formally granting to each tribal member their own title to land. However, the land could not be granted to Māori in the same manner it had been to the settlers by way of its sister Act, the Crown Grants Act (No 1) 1862, because the Crown had made promises of providing areas of mahinga kai for tribal members in the deed of purchase. First, it was agreed that the land would remain within the tribe and could not be "alienated outside of Maori". Secondly, land also had to be set aside for schools, hospitals and conditions needed to be placed on the land if it was to be leased. ${ }^{51}$ Walter Mantell had also made specific promises to individual members of the tribe for their help in the sub-division. ${ }^{52}$ All these nuances needed to be resolved in an Act separate from the Crown Grants Act (No 1) 1862, which applied to the settlers. This is why the Crown Grants Act (No 2) 1862 appears to be tailor-made for the particular needs of Ngāi Tahu. The first section simply gives the name of the Act. The second section says that it was lawful for the Governor alone to fulfil any promise or engagement made on the Crown's behalf if there was evidence in writing, whether the land had been surveyed or not:

It shall be lawful for the Governor at any time to fulfil any contract promise or engagement heretofore made by or on behalf of Her Majesty whereof there is evidence in writing with respect to any Land within the Colony whether the same shall have been surveyed or defined by metes and bounds or not.

49 John Paratene as cited in "Maori Meeting at Port Cooper" The Maori Messenger: Te Karere Maori (New Zealand, 1 January 1860) at 3-4.

50 Governor Gore-Browne as cited in "Maori Meeting at Port Cooper", above n 49, at 6.

51 Buller, above n 6, at 3

52 Alexander Mackay A Compendium of Official Documents Relative to Native Affairs in the South Island (Luckie and Collins, Nelson, 1872) vol 2 at 118. 
In other words, the Act confirmed the customs of the people that had been debated on Buller's arrival. Section 3 goes on to declare that where promises were made to Māori in regards to any land ceded by Māori, whether there was written evidence or not, then the Governor in Council with his Ministers must lawfully fulfil those contacts or promises. The Crown Grants Act (No 2) 1862 has been used only once, which was for the granting of individual title on the Kaiapoi Māori Reserve.

While the Crown Grants Act (No 2) 1862 was passed in 1862, the actual lands were not "granted" until 19 September 1865, when each tribal member was allocated 14 acres. There are two key points to this Act. First, the grants were issued a month before the Native Land Court was created on 30 October $1865 .{ }^{53}$ In other words, what was to occur on the Kaiapoi Māori Reserve was to occur outside of the Native Land Act 1862. Secondly, it is likely that the Crown Grants Act (No 2) 1862 was meant to be an acknowledgement of the agreements made between Ngāi Tahu at Kaiapoi, not just in relation to the individual titles, but also in regard to their customs and traditions and in particular their mahinga kai.

The records of Mantell, Buller and the Ngāi Tahu elders were all clear that communal title led to too many arguments upon the Reserve. To resolve the situation, rūnanga agreed to their own subdivision of the land, which was more likely influenced by the tribal practices than Buller's notion of individualisation. And it is easy to see how this was achieved once a closer look is taken at the way the allotments were arranged upon the Reserve. Indeed, Buller himself admits that the sections were allocated along hapu lines. ${ }^{54}$ Historians, like the Crown, living outside the tribal mind, will not see the patterns. Tribal historians, however, will immediately spot the patterns of how the people arranged themselves.

A critical aspect of the individual title was the point agreed to in rūnanga: that the land was to be inalienable to persons other than Māori. That is, the land was to be traded and exchanged as it always had been, but the system was to be internal to the tribe. The exchange of land among tribal members is simply a custom well-known and recorded. In fact, as soon as the grants had been made, tribal members immediately started exchanging taonga for burial sites among themselves so as to accommodate their new arrangements. ${ }^{55}$

The "Kaiapoi Experiment", as it became known, was important in that it was designed to meet the specific needs of Ngāi Tahu. The experiment was carried out in nearby villages at Rapaki, Wairewa, Port Levy and Akaroa. It recognised their traditions to property and, in particular, individual property rights. Equally important is that it occurred before the Native Land Acts. The question that needs to be asked then is how did the Kaiapoi Experiment fare? The key point here is

53 Rawson, above $\mathrm{n} 47$, at 3.

54 Buller, above n 6, at 5 .

55 "Native Lands Court" Lyttelton Times (Lyttelton, 22 April 1868) at 2. 
that the land allocated was never enough and this was a major problem. The question is whether they maintained their holdings or not. The answer seems to be that the Kaiapoi people managed to maintain their land through to the turn of the century. In fact, little land appears to have been alienated, simply because it was an accepted rule among the people and the Crown that the land could not be alienated as stated in the original rules. ${ }^{56}$

However, problems emerged by the end of the century when Pakeha again insisted that their ideal for Māori land was communal title and equality of ownership. The situation came to a head in 1895 with the case Mahupuku v Australian Mutual Provident Society wherein it was held that "inalienable land" was not divisible by will. ${ }^{57}$ This was a problem for the Kaiapoi people, who had followed the tradition of ōhāki - final words - where the dying elder determined future ownership using a complex set of rules and customs as to who would inherit land and property. The idea of succession has no real equivalent among Māori. Today, it is simply assumed that descendants automatically inherited or succeeded, although there is no direct evidence for this. Rather, evidence suggests that ownership by inheritance was determined by ōhākī as based on customs. ${ }^{58}$ Ngāi Tahu were well aware of their traditions and customs to lands and other types of property, as seen in the case of Buller's negotiations during the sub-division of Kaiapoi many of their traditions were applied to who was entitled to land upon the Reserve. The two guiding rules for take whenua appeared to be take-tīpuna (ancestral descent) and ahi-kā (occupation). One custom that appears time and time again as the decisive reason is that if family members no longer resided upon the land, they simply lost their take to the land.

What we can see, however, is the Native Land Court introducing ideas that were simply foreign to Ngāi Tahu. In one Court sitting, the right of a tamaiti-whāngai (a foster child) to succeed to land ownership was being considered. The elders expressed their concern at the idea of adopted children inheriting, stating, "Hei mea ahua touhou tenei [i] whakatau ki tenei motu" - "this is a foreign idea introduced from the North Island". Another elder said the same in English: "It has not been apparent from the evidence that the custom of tamaiti whangai was a practice of the Ngai Tahu". ${ }^{9}$ Again the point needs to be made that Ngāi Tahu take whenua was complex. The issue of individual rights was part of a larger issue of elaborate tribal property rights that the Crown was barely equipped to manage. The Crown's failure was not simply a failure to acknowledge individual property rights; it was a failure of intellectual flexibility. For the Crown, which was unable to manage North Island property rights, Ngāi Tahu's property system appeared far too daunting. In the end the Crown could only project itself onto Māori. .

56 Rawson, above $\mathrm{n} 47$, at 13.

57 Mahupuku v Australian Mutual Provident Society (1894) 13 NZLR 246 (SC) at 249.

58 Rawson, above n 47, at 13.

59 (1901) 13 South Island MB at 115-116. 
The Mahupuku case was dangerous for the Kaiapoi people because ever since the grants had been allocated the people had been operating under the notion that ōhākī was a legitimate custom. Capital investments in the properties, mortgages and debt liabilities had all accumulated and now it had been decided that ownership of the land was invalid, leading to a crisis. The situation was also arising wherein potential successors were suing the lessee who had already paid the owner as stated in the will. ${ }^{60}$ The outcome was that the Kaiapoi land was turned into communal title by default, something the community had always opposed. Because the idea of succession was seen as superseding ownership by will, the land was subjected to multiple ownership, which was really a variation of communal title. This had been something that that the Kaiapoi people had managed to avoid because they had operated under the Crown Grants Act (No 2) 1862, not the Native Land Court. In fact, the tradition had been ongoing for 30 years before the Native Land Court decided to express an opinion. ${ }^{61}$ Approximately $70-80$ wills were potentially invalid. ${ }^{62}$

The result was that in 1911, a Royal Commission led by Walter Edward Rawson, a judge of the Native Land Court, was established to resolve the emergency that had arisen. Rawson's decisions are not themselves relevant to this article. What is relevant is the evidence provided by the elders of their customs relating to the land. Succession was essentially a Western rule wherein the descendants were able to succeed to the estate in an equal manner. It was hardly a traditional custom among Māori, Ngāi Tahu, or other iwi. Māori have quite specific traditions in regards to ōhākī whether it concerned land, fishing rights, pounamu, whakapapa or waiata. In fact Firth says that the custom of ōhākì' was part of the machinery of law within the community. ${ }^{63}$ The Upoko Rūnanga, Taituha Hape recalled the traditions of ōhākī in his petition to the Crown wherein he stated that ōhāki were based on the "grounds of ancient right, protection of parents against undutiful children". ${ }^{64}$ Ōhāki was a simply another custom by which the people managed their properties. The elder Taare Tikao gave evidence noting that "ohaki was practised for many generations by our ancestors, and was the only way of leaving property". ${ }^{65}$ However, the Native Land Court insisted that their system of succession should hold. Again the Crown failed to understand tribal custom and succession led to a communal title by default because it meant multiple ownership. John Hopere Uru explained the implications of the Native Land Court ruling as follows: ${ }^{66}$

60 At 10

61 At 4 .

62 "Wills Upset" Hawera \& Normanby Star (Hawera, 14 September 1910) at 8.

63 Firth, above $\mathrm{n} 9$, at 358

64 Rawson, above $\mathrm{n} 47$, at 5.

65 "Statement of Hone Tare Tikao in reference to the Inquiry with regard to the Legality of Wills relating to Restricted Lands" as reproduced in Rawson, above n 47, at 18 (emphasis in original).

66 Evidence of John Hopere Uru as reproduced in Rawson, above n 47, at 13. 
At present time these 14-acre divisions would be so distributed amongst next-of-kin as to be useless. In case my wife interested in 14 acres, sixty-two owners, smallest share 5/2304 of the whole. This would really be absurd - not worth cost of orders.

The Kaiapoi people were endangered two times: first when their land was places in communal title before the Crown Grants Act (No 2) 1862; and secondly when the Native Land Court decided to remove the custom of ōhākī. Between 1865 when the Crown Grants were allocated to the 1911 Royal Commission, Kaiapoi land had not been alienated and Rawson noted this in his report. ${ }^{67}$ In other words, individual title worked when it operated within a kind of tribal regulatory framework.

The Crown's push towards communal title in 1862 and 1911 was fuelled by Western property concepts, rather than seeking to understand how Ngāi Tahu land title really operated. The tragedy was that, rather than create a functional system, the Crown made decisions that were based on false projections that ran counter to the perceptions of their own agents on the ground. The period of relative functionality from $1848-1865$ was a rare moment in colonial history where Ngāi Tahu was able to operate using a property rights system proximate to their pre-contact one.

The Kaiapoi Experiment should not be seen as something unique to Kaiapoi Ngāi Tahu nor indeed Ngāi Tahu. The system of land allocation on an individual basis ran right through the tribe and in 1925 Ngāi Tahu gathered again en-mass at Kaiapoi to ensure their individual property rights were again protected in what was to eventually become the Ngāi Tahu Trust Board. And again, as with the Kaiapoi Experiment, the Crown insisted on its own agenda of communal equity.

\section{THE 1925 NGĀI TAHU WHAKAPAPA HUI}

The 1925 Ngāi Tahu hui at Kaiapoi is possibly the most important gathering of Ngāi Tahu other than the campaigns the Kaiapoi-Murihiku chiefs led against Ngāti Toa in the 1830s.

The hui was in response to the 1921 Native Land Claims Royal Commission (the Jones Strauchon Ormsby Commission) which recommended the tribe receive $£ 354,000$ as compensation for the loss of lands. ${ }^{68}$ The history of the Ngāi Tahu Claim is well documented in Harry Evison's Te Waipounamu and need not be recounted here. ${ }^{69}$ The question before the tribe was who was entitled to the compensation. Today, Ngāi Tahu see this hui as the key moment where the tribe gathered to establish the whakapapa files which now is the defining statement of tribal identity. However, the whakapapa of Ngāi Tahu ran in tandem with the tribe's understanding of take whenua.

67 Rawson, above n 47, at 19.

68 Robert Noble Jones, John Strauchon and John Ormsby "Report of the Native-Land Claims Commission" [1921] I AJHR G5 at 40.

69 Harry Evison Te Waipounamu, the Greenstone Island: a History of the Southern Māori during the European Colonization of New Zealand (Aoraki Press, Christchurch, 1993). 
To determine who had rights, a Commission was established under s 29 of the Native Land Amendment Act 1923, which allowed the Native Land Court to sit and determine who was entitled to the $£ 354,000$. This became the largest Ngāi Tahu hui of its time and remains so to this day.

During the hui two factions emerged. One committee was chaired by Werita Tainui Pitama. ${ }^{70}$ The committee that challenged the views of Werita Pitama was chaired by RM Taiaroa. ${ }^{71}$ It would be a mistake to see this as an argument between the southern and northern Ngāi Tahu. It was simply a split along the lines of take whenua tribal land tenure.

The committee led by Pitama believed that the distribution belonged to the descendants of those who lived within the boundaries of the 1848 Canterbury Purchase. ${ }^{72}$ For this committee, those who lived outside the boundary in $1848 \mathrm{did}$ not have a right because they had not been in occupation of the land. The principal of ahi kā was important and was justified on the basis that many of the Canterbury-Bank's Peninsula region had been excluded from the Tîtī Islands. Taiaroa's committee held to the view that the sole issue was a matter of ancestry and that it did not matter whether their ancestors lived elsewhere. The debates were fierce. But what is important is that each claimant was thoroughly cross-examined in terms of their history and whether the ancestor had evidence of occupation. Both parties agreed that the whakapapa of the tribe needed to be confirmed and as a result the Chief Judge RN Jones managed to encourage both sides to form a committee so that they could assess the whakapapa of those who belonged. One newspaper report recorded: ${ }^{73}$

Scores of Natives' have come to the hui armed with family trees or whakapapas committed to writing.

Each side, by agreement with the judge, has set up a committee, and these two bodies have undertaken to compare and collate the genealogies and put them into proper form for presentation to the Court.

Not surprisingly, they found common ground in their whakapapa with the Court later confirming most of the lists provided from the Whakapapa Committee. ${ }^{74}$ The final outcome decided was that tribal members alive in 1848 were found to be entitled to the claim. However, Pitama also managed to ensure that the Ngāi Tahu claim remained with the tribe and that other iwi did not have a right. On that basis the tribes who claimed by descent but had no occupation rights were excluded. The

70 Members of this committee were Hoani Matiu, W D Barrett (Secretary), Ihakara H Karaitiana, Wi Rehu, Hoani Mamaru, William Anglem, W Taipana, Tuapaoa Whitau, Duncan Hamstead and Tiemi Hipi.

71 Members of this committee were T McDonald, J Wixon, J Paiki, P Tau, Te Hau Korako, T M Erihana, A Wixon, P McDonald and T Spencer.

72 "Notes by Werita Tainui Pitama at the Native Land Court Sitting at Tuahiwi, 1925" (Personal Collection, RTM Tau Archives, Tuahiwi).

73 "The Tuahiwi Hui" Evening Post (Wellington, 22 January 1925) at 8; "Ngai Tahu Claims" The Press (Christchurch, 21 February 1925) at 3; and "The Hui at Tuahiwi" Otago Daily Times (Dunedin, 7 February $1925)$ at 2.

74 (1925) 23(a) South Island MB 4 February 1925. 
Court ruled on one list: "Their rights have long since grown cold, and no Court would admit them for inclusion to any title to the land". ${ }^{75}$

More important than the decision, however, was that despite the debate about who was entitled, the Whakapapa Committee immediately set about identifying each member's right to the $£ 354,000$. The Whakapapa Committee allocated each ancestor a share to the 1,551 elders who were believed to be alive in 1848. Today, the original Ngāi Tahu whakapapa files have the shares allocated to each ancestor. Most ancestors inherited eight shares, but it was also decided to allocate the senior kaumātua 10 shares instead of eight. The Native Land Court announced the tribe's decision on 12 March $1925{ }^{76}$

Three years later, Ngāi Tahu elders met as a board to further consider the actual distribution and allocation of the $£ 354,000$. They passed three resolutions. The first was that $£ 150,000$ was to be distributed to tribal members. Another $£ 150,000$ was to be invested and the interest was to be distributed in perpetuity to tribal members and the remaining $£ 54,000$ was to be used to cover any remaining legal costs, contributions made by tribal members and anything left was to be set aside to cover tribal members yet to enrol and receive their tribal entitlement. The logic behind these recommendations made clear in that the $£ 354,000$ was seen as an entitlement or, in today's language, a property right. However they were also thinking for the tribe as a collective by setting aside an investment for tribal members. The important point here is that they neatly managed to declare what the individual interest was and where the collective interest sat, the nested layers of pre-contact property rights apparent in their deliberations.

The 1925 Ngāi Tahu hui was, in a sense, the Kaiapoi Experiment updated and modernised nearly 80 years later. The reason the hui was so contentious was because tribal members had kept their records of what they had lost during the original land purchases and their task was to articulate these losses into a contemporary form - shares. And, just as Ngāi Tahu had managed to articulate its own sense of property rights and take whenua, the Crown decided to override the tribe's decision and impose a collective share-holding system on the tribe as it had done with the Kaiapoi Experiment.

This change in policy from individual shares can be traced to a conference held between Ngāi Tahu leaders and the Acting Native Affairs Minister, Frank Langstone, in 1938. The Labour Party saw the settlement in terms of distributive justice as opposed to property rights. It was part of their cradle to grave ideology. Evidence of this is apparent when Langstone showed his concern with the tribal demographics. To his way of thinking if there were larger tribes than Ngāi Tahu, "it would

75 (1925) 23(a) South Island MB 4 February 1925.

76 Ngāi Tahu Māori Trust Board Ngaitahu kaumatua alive in 1848, as established by the Maori Land Court in 1925 and the Ngaitahu Census Committee in 1929 (Wright \& Carman, Wellington, 1967) at 1. 
seem ridiculous to give a lot of money to a few people and a little money to a lot of people". ${ }^{77}$ The telling remark came out the end when Langstone said: ${ }^{78}$

The Government is considering National Superannuation, Liberalisation of pensions. The maoris are going to get that. ... If it is going to be done, it is no good us double-banking. There is a sum of money and the Board can deal with that in a manner that would be of benefit to those people who are not covered by our pension system.

In other words, the settlement was to align with and supplement Labour Party policy. It was seen as a means of providing social equity and the Ngāi Tahu Trust Board was to be an instrument of distribution to cover those not covered by the government. It was not to be a body that would provide any supplementation to the pension because that would have been seen as a "doublebanking", what is now called double dipping. This view can only result if wealth is seen within the context of social equity to be solved by distribution. This was what the Labour Party Manifesto declared in 1935: ${ }^{79}$

Labour will insist that money becomes an instrument of distribution ... . In a sane distributive system, of which a State Bank is the key, lies the way to a golden age.

This prevailing view was confirmed in s 20 of the Ngaitahu Trust Board Act 1946, which declared:

Notwithstanding anything contained in this or any other Act, none of the Ngaitahu beneficiaries shall acquire or be deemed ever to have acquired any interest, whether vested or contingent, or legal or equitable, in the moneys in the Fund.

There can be no clearer example where a tribal council had deliberately gathered to debate and agree on individual tribal shares and rights among themselves, only to have a settler government impose collective distribution system that removed individual rights to property.

\section{CONCLUSION}

When we consider the notion of property among Māori, we need to remove from our minds the irrelevant musings of Sewell. Sewell was no expert on take whenua. That it has been automatically assumed individual property rights were a Western tradition is simply a case of Māori reacting to a straw man or at least a half-formed idea on property.

77 "Supporting Papers to the Evidence of David Armstrong" (Wai 27, M17, Doc 43, 1991) inquiry document for Wai 27, above $\mathrm{n} 28$.

78 "Supporting Papers to the Evidence of David Armstrong", above n 77.

79 W David McIntyre and WJ Gardner (eds) Speeches and Documents on New Zealand History (Clarendon Press, Oxford, 1971) at 318. 
The Kaiapoi Experiment stands as an insight into Ngāi Tahu property rights. The record shows that these rights were structured within a community to meet the collective and individual interests of the tribe. Ngāi Tahu land tenure was established, internally consistent and unassailable not just because of the evidence of the systems of wakawaka and ōhākī, but also because the evidence exists. If Ngāi Tahu had had communal property rights, then the Kaiapoi Reserve would not have been so contested over the decades. But the reality was much more complicated. Communal property and individual property were part of a rich quilt of take whenua. While the Crown kept operating in a manner that ignored tribal systems, Kaiapoi Ngāi Tahu consistently responded in a manner that confirmed that their property rights system was one that saw individual title prescribed through a complex set of rules and customs in a communally-validated manner.

The Crown could only deploy binary arguments of communal title and individual property rights because the alternative meant delving into a system of land tenure and take whenua that could only lead to it recognising alternative systems and institutions far too complicated for the Native Land Court to manage. The purpose of the Native Land Court was to facilitate the alienation of Māori land, not to recognise impregnable systems of property. Therefore, the Kaiapoi Experiment was destined to fail. So too the ideas of ōhākī and the developed system of "shares" in 1925. Thus, while the Crown had already acquired the land, it still sought an even greater control. Colonisation is, at its core, about power and control. The Kaiapoi Rūnanga decisions did not sit with imperial policy. 